\title{
Evaluation of Knowledge Levels, Attitudes and Behaviors Among the Relatives of Patients Infected with Hepatitis $B$
}

\author{
Hepatit B Hasta Yakınlarının Bilgi Düzeylerinin, Tutumlarının ve Davranıșlarının \\ Değerlendirilmesi
}

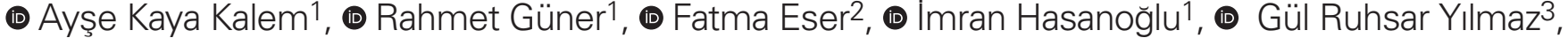 \\ (D) Mehmet Akın Taşyaran1
}

${ }^{1}$ Ankara City Hospital, Clinic of Infectious Diseases, Ankara, Turkey

2University of Health Sciences Turkey, Dışkapı Yıldıım Beyazıt Training and Research Hospital, Clinic of Infectious Diseases and Clinical Microbiology, Ankara, Turkey

${ }^{3}$ Süleyman Demirel University Faculty of Medicine, Department of Infectious Diseases, Isparta, Turkey

\begin{abstract}
Objectives: To measure the knowledge level and evaluate the attitudes and behaviors of the relatives of patients with chronic hepatitis B.

Materials and Methods: This study was conducted in Ankara Atatürk Training and Research Hospital, Clinic of Infectious Diseases and Clinical Microbiology. A self-explanatory questionnaire comprising was designed to evaluate and compare the knowledge, attitudes, and awareness of the participants regarding hepatitis $B$ infection. The patients were followed up for at least one year with a diagnosis of hepatitis B virus (HBV) infection.

Results: The mean age of 106 relatives of patients was $40.6 \pm 11.8$ years. The knowledge level of women about the disease, transmission routes, and protective measures was significantly better than men. The importance of receiving a vaccination and separating personal belongings that can be contaminated by blood was known by the majority $(86.9 \%$ and $86.8 \%$, respectively), but the vaccination rate was $49.1 \%$. Age was inversely correlated with knowledge about transmission routes. The educational level had a positive impact on the knowledge level of relatives.

Conclusion: In the fight against HBV infection, informing the whole society, especially patients with HBV and their relatives, about transmission routes and prevention of HBV transmission is vital.

Keywords: Hepatitis B, patient relative, knowledge level, vaccination
\end{abstract}

ÖZ

Amaç: Kronik hepatit B'li hasta yakınlarının bilgi düzeyini ölçmek ve tutum ve davranışlarını değerlendirmektir.

Gereç ve Yöntemler: Bu çalışma Ankara Atatürk Eğitim ve Araştırma Hastanesi, Enfeksiyon Hastalıkları ve Klinik Mikrobiyoloji Kliniği'nde yapıldı. Katılımcıların hepatit B enfeksiyonu ile ilgili bilgi, tutum ve farkındalıklarını değerlendirmek ve karşılaştırmak için açıklayıcı bir anket tasarlandı. Hastalar en az bir yıl süreyle hepatit B virüs (HBV) enfeksiyonu açısından izlendi.

Bulgular: Yüz altı hasta yakınının yaş ortalaması 40,6 411,8 yıldı. Kadınların hastalık, bulaşma yolları ve koruyucu önlemler hakkındaki bilgi düzeyleri erkeklerden önemli ölçüde daha iyiydi. Aşı yaptırmanın ve kan bulaşabilecek kișisel eşyaları ayırmanın önemi çoğunluk tarafından biliniyordu (sırasıyla; \%86,9 ve \%86,8), ancak aşılama oranı $\% 49,1$ idi. Yaș, bulașma yolları hakkındaki bilgilerle ters orantılıydı. Eğitim düzeyi, akraba bilgi düzeyini olumlu yönde etkilemiştir. Sonuç: HBV enfeksiyonu ile mücadelede tüm toplumu, özellikle HBV'li hastalar ve yakınları bulaşma yolları hakkında bilgilendirmek ve HBV bulaşının önlenmesi hayati önem taşımaktadır.

Anahtar Kelimeler: Hepatit B, hasta yakını, bilgi seviyesi, aşılama

Kaya Kalem A, Güner R, Eser F, Hasanoğlu I, Yılmaz GR, Akın Taşyaran M. Evaluation of Knowledge Levels, Attitudes and Behaviors Among the Relatives of Patients Infected with Hepatitis B. Viral Hepat J. 2021;27:63-67.

Address for Correspondence: Ayşe Kaya Kalem PhD, Ankara City Hospital, Clinic of Infectious Diseases, Ankara, Turkey Phone: +90 5063009586 E-mail: dr.aysekaya09@hotmail.com ORCID ID: orcid.org/0000-0002-4759-0066 Received: 07.12.2020 Accepted: 20.06.2021

${ }^{\circ}$ Copyright 2021 by Viral Hepatitis Society / Viral Hepatitis Journal published by Galenos Publishing House. 


\section{Introduction}

The hepatitis B virus (HBV) infection is an important cause of morbidity and mortality as it causes both acute-chronic viral hepatitis and complications such as cirrhosis and hepatocellular cancer (HCC). Chronic HBV infection is the cause of more than half of HCCs which represent approximately $75-90 \%$ of all primary liver cancers. Besides, the incidence of cirrhosis in patients with untreated chronic hepatitis B is at least $40 \%$ (1). In our country, more than half of the liver transplantation cases performed between 2012-2016 were associated with viral hepatitis, especially HBV (2).

The low awareness, especially in the at-risk population that was born before the adoption of vaccination programs, may increase disease burden and death due to transmission and HBV complications (2). In Turkey, one out of three people over the age of 18 are estimated to have been infected with HBV, and it is thought that there are more than 2 million adults with hepatitis B surface antigen ( $\mathrm{HBsAg}$ ) positivity. Only about $12 \%$ of these people were found to be aware of their condition (3). In our country, since HBV infection is the endemic and horizontal transmission is prominent, relatives who share the same house with the patients are at risk for transmission. It will be effective to reduce the prevalence of HBV by identifying missing and inaccurate information about HBV in society, especially in patients and their relatives, and increasing the level of knowledge among people, and organizing educational approaches to create attitude and behavior change (4). In our country, it is known that the vaccination rate of the high-risk population is around 5\% (4).

This study aimed to evaluate the level of knowledge and attitudes of the first-degree relatives who share the same house with patients in terms of their knowledge regarding disease definition, modes of transmission, risk factors, prevention methods, and consequences of the disease.

\section{Materials and Methods}

\section{Study Group}

The study included 106 volunteers who were older than 18 years of age and shared the same house with an HBsAg-positive patient to which they were related (first-degree). Only one relative of patients was included in the study group. The patients were admitted to the Ankara Atatürk Training and Research Hospital between 01.06.2014-01.07.2014 and were followed up for a duration of at least one year at our center.

\section{Ethical Issues}

This study was approved by the Institutional Ethics Review Committee of Ankara Yıldırım Beyazıt University Faculty of Medicine. The relatives of the patients were informed, and verbal and written informed consent was obtained from them before they took the questionnaire.

\section{Study Instrument}

A self-explanatory questionnaire comprising of 24 questions was designed to evaluate and compare the knowledge, attitudes, and awareness of the participants regarding hepatitis B infection. The questionnaires were completed under observation without any intervention. The content of the questionnaire was created by scanning national and international publications and the diseaserelated questions we received from patients. The questions were open-ended, but in some questions, options were given to determine the views of the participants. The questionnaire was comprised of the following sections:

- Demographics: age, gender, education, socioeconomic status,

- Knowledge of HBV: sources, self-assessment, knowledge items,

- Attitudes and behaviors towards HBV,

- Disease concerns and difficulties.

\section{Statistical Analysis}

Statistical analyses were performed using SPSS version 15.0 (SPSS, Chicago, IL, USA). In the study, numerical data were shown with mean and standard deviation, and categorical data were shown with frequency and percentages. Chi-square tests were used for categorical data comparison between independent groups, and the Kruskal-Wallis test was used for multiple group analysis for ordinal data. The internal consistency of the questionnaires used in the study was evaluated with Cronbach's alpha value. In all statistical analyses, obtaining a p-value $<0.05$ was considered statistically significant.

\section{Results}

\section{Sociodemographic Characteristics}

A total of 106 relatives, 63 (59.4\%) females and 43 (40.6\%) males were included in the study. The mean age of the participants was $40.6 \pm 11.8$ years.

\section{Awareness}

The responses of the participants to the questions that measured their level of awareness are shown in Table 1.

In our study, women were more aware that hepatitis B was an infectious disease affecting the liver $(p=0.001)$ and a contagious disease $(p=0.039)$ than men.

\section{Knowledge Level}

The responses of the participants to the questions that measured their level of knowledge are shown in Table 2.

Women had more information about the risk of transmission to relatives $(93.7 \%, p=0.012)$, protection methods (vaccination: $100 \%, p<0.001$; separation of personal items with blood contact: 95.2\% $p=0.002$ ), complications (death: 49.2\%, $p=0.015$; liver transplantation $31.7 \%, p=0.023$ ) and treatment purpose (stopping viral replication: $76.2 \%, \mathrm{p}<0.001$ ), while men had higher rate of the misinformation that hepatitis B could turn into hepatitis $\mathrm{C}$ spontaneously $(93 \%, p<0.001)$. Participants under the age of 30 were more aware that hepatitis $B$ was an infectious disease (86.4\%, $p=0.004$ ) and could be transmitted through vertical $(100 \%$, $p=0.001)$ and sexual transmission $(72.7 \%, p<0.001)$.

The knowledge that inactive carriage was contagious and required follow-up was greater in those under 30 and over 50 years of age $(100 \%, p=0.001)$. All participants over the age of 50 knew that treatment aimed to stop viral replication $(p=0.003)$, and the disease could cause cirrhosis $(p=0.007)$. Persons with higher education had more knowledge about the aim of reducing viral 
Table 1. Distribution of participants' awareness level about HBV infection

\begin{tabular}{|c|c|c|}
\hline & n & $\%$ \\
\hline \multicolumn{3}{|l|}{ What does hepatitis B infection mean? } \\
\hline It is a microbial disease affecting blood & 34 & 32.1 \\
\hline $\begin{array}{l}\text { An important disease in which the liver is affected } \\
\text { by a germ }\end{array}$ & 81 & 76.4 \\
\hline Icterus is seen & 62 & 58.5 \\
\hline It is an infectious disease & 62 & 58.5 \\
\hline
\end{tabular}

What other hepatitis germs do you know other than hepatitis $B$ ?

\begin{tabular}{|l|l|l|}
\hline Hepatitis A & 65 & 61.3 \\
\hline Hepatitis C & 98 & 92.5 \\
\hline Hepatitis D & 30 & 28.3 \\
\hline
\end{tabular}

Does the liver regenerate in patients with chronic hepatitis?

\begin{tabular}{|l|l|l|}
\hline Yes & 45 & 42.5 \\
\hline No & 48 & 45.3 \\
\hline
\end{tabular}

Does hepatitis occur only with hepatitis germs?

\begin{tabular}{|l|l|l|}
\hline Yes & 53 & 50 \\
\hline No & 38 & 35.8 \\
\hline
\end{tabular}

Can hepatitis B spontaneously return to hepatitis C?

\begin{tabular}{|l|l|l|}
\hline Yes & 75 & 70.8 \\
\hline No & 22 & 20.8 \\
\hline
\end{tabular}

Is it necessary to have icterus for a person to have hepatitis?

\begin{tabular}{|l|l|l|}
\hline Yes & 41 & 38.7 \\
\hline No & 55 & 51.9 \\
\hline
\end{tabular}

HBV: Hepatitis B virus

Table 2. Distribution of participants' knowledge level about HBV infection

\begin{tabular}{|c|c|c|}
\hline & $\mathbf{n}$ & $\%$ \\
\hline \multicolumn{3}{|c|}{$\begin{array}{l}\text { Can people infected with hepatitis B become only "silent } \\
\text { carriers"? }\end{array}$} \\
\hline Yes & 89 & 84 \\
\hline No & 10 & 9.4 \\
\hline
\end{tabular}

A person, who has been informed that $\mathrm{s} / \mathrm{he}$ is a silent carrier, does not need to be followed and does not transmit the disease, is that correct?

\begin{tabular}{|l|l|l|}
\hline Yes & 20 & 18.9 \\
\hline No & 83 & 78.3 \\
\hline
\end{tabular}

Are the relatives of patients at risk for hepatitis $B$ infection?

\begin{tabular}{|l|l|l|}
\hline Yes & 92 & 86.8 \\
\hline
\end{tabular}

No

\begin{tabular}{l|l|l|}
14 & 13.2 \\
\hline
\end{tabular}

What are the modes of transmission?

\begin{tabular}{|l|l|l|}
\hline Contact with patient blood & 106 & 100 \\
\hline
\end{tabular}

\begin{tabular}{|l|l|l|}
\hline During sexual activity & 78 & 73.6
\end{tabular}

\begin{tabular}{|l|l|l}
\hline During surgery & 88 & 83
\end{tabular}

During dental treatment

During childbirth

Acupuncture, tattoo, during piercing
Table 2. continued

\begin{tabular}{|c|c|c|}
\hline $\begin{array}{l}\text { With the common use of instruments in } \\
\text { contact with blood in the barbershop }\end{array}$ & 92 & 86.8 \\
\hline Kissing on the lips & 40 & 37.7 \\
\hline $\begin{array}{l}\text { Sharing kitchen utensils with infected } \\
\text { person }\end{array}$ & 29 & 27.4 \\
\hline $\begin{array}{l}\text { With mouth and nose secretions caused by } \\
\text { sneezing }\end{array}$ & 37 & 34.9 \\
\hline With mosquito bite & 33 & 31.1 \\
\hline With phlegm, sweat, tears, breast milk & 29 & 27.4 \\
\hline $\begin{array}{l}\text { Sharing the same environment with the } \\
\text { patient }\end{array}$ & 27 & 25.5 \\
\hline Shaking hands with infected person & 14 & 13.2 \\
\hline Respiratory tract & 27 & 25.5 \\
\hline $\begin{array}{l}\text { Shared toilet, bathroom, with clothes, } \\
\text { kitchen utensils }\end{array}$ & 25 & 23.6 \\
\hline With stress & 21 & 19.8 \\
\hline \multicolumn{3}{|l|}{ What are the ways to prevent hepatitis B? } \\
\hline $\begin{array}{l}\text { Separation of personal items with blood } \\
\text { contact, such as toothbrushes and nail } \\
\text { clippers }\end{array}$ & 92 & 86.8 \\
\hline Vaccination & 95 & 89.6 \\
\hline Single partner sexual activity & 42 & 39.6 \\
\hline Using a condom & 42 & 39.6 \\
\hline Washing foods with water & 60 & 56.6 \\
\hline Using bottled water & 26 & 24.5 \\
\hline \multicolumn{3}{|l|}{ What is the prognosis for hepatitis B? } \\
\hline Cirrhosis of the liver & 96 & 90.6 \\
\hline Liver cancer & 48 & 45.3 \\
\hline Death & 42 & 39.6 \\
\hline Liver transplantation & 44 & 41.5 \\
\hline \multicolumn{3}{|c|}{ Does hepatitis B need to be monitored in a health facility? } \\
\hline Yes & 106 & 100 \\
\hline No & 0 & 0 \\
\hline \multicolumn{3}{|c|}{ Is there any medication for chronic hepatitis B infection? } \\
\hline Yes & 77 & 72.6 \\
\hline No & 26 & 24.5 \\
\hline \multicolumn{3}{|l|}{ If there is a treatment, what are the aims? } \\
\hline $\begin{array}{l}\text { Stopping the replication of virus and } \\
\text { inactive it }\end{array}$ & 62 & 58.5 \\
\hline Stopping the progression of the disease & 77 & 72.6 \\
\hline Preventing hepatitis B turns into icterus & 60 & 56.6 \\
\hline Preventing liver failure & 39 & 36.8 \\
\hline Eliminating the disease completely & 32 & 30.2 \\
\hline \multicolumn{3}{|c|}{ Can a person infected with hepatitis B donate blood? } \\
\hline Yes & 0 & 0 \\
\hline No & 106 & 100 \\
\hline HBV: Hepatitis B virus & & \\
\hline
\end{tabular}


replication through treatment $(69.1 \%, \mathrm{p}=0.01)$ and stopping the progression of disease $(81.8 \%, \mathrm{p}=0.017)$. Also, they were more knowledgeable about the sexual transmission (using condoms: $56.4 \%, \mathrm{p}=0.001$; single partner sexual activity: $49.1 \%, \mathrm{p}=0.012$ ) when compared to those with lower education.

\section{Sources of Information}

Although the most common source of information was physicians for all groups, the rate of those who applied to the internet for information was higher in the group under 30 years of age $(59.1 \%, p<0.001)$ and with a high level of education $(38.2 \%$, $\mathrm{p}=0.001$ ) (Table 3).

\section{Attitudes and Behaviors}

The responses of the participants to the questions that measured their attitudes and behaviors are shown in Table 4. The rate of those who had HBV screening was lower in the group with higher education level $(p=0.002)$.

Table 3. Distribution of information sources reported by participants.

\begin{tabular}{|c|c|c|}
\hline & $\mathrm{n}$ & $\%$ \\
\hline \multicolumn{3}{|c|}{ Where did you get information about hepatitis B? } \\
\hline Doctor & 82 & 77.4 \\
\hline Internet & 29 & 27.4 \\
\hline Family & 13 & 12.3 \\
\hline Newspapers, magazines & 4 & 3.8 \\
\hline
\end{tabular}

Table 4. Distribution of participants' attitude and behavior

\begin{tabular}{|c|c|c|}
\hline & $\mathbf{n}$ & $\%$ \\
\hline \multicolumn{3}{|c|}{ Did you get a hepatitis screening test? } \\
\hline Yes & 96 & 90.6 \\
\hline No & 10 & 9.4 \\
\hline
\end{tabular}

Would you be more afraid if your relative had hepatitis $C$ or $D$ instead of hepatitis B?

\begin{tabular}{|l|l|l|}
\hline Yes & 74 & 69.8 \\
\hline No & 29 & 27.4 \\
\hline
\end{tabular}

Which of the following did you do when you learned that your spouse/sexual partner had hepatitis B?

\begin{tabular}{|l|l|l|}
\hline Blood screening test & 72 & 67.9 \\
\hline Vaccination & 52 & 49.1 \\
\hline I avoided living in the same house & 0 & 0 \\
\hline I avoided sexual intercourse & 11 & 10.4 \\
\hline Using condoms & 14 & 13.2 \\
\hline $\begin{array}{l}\text { After learning about the disease, I decided not } \\
\text { to have children. }\end{array}$ & 0 & 0 \\
\hline
\end{tabular}

Which of the following situations occurred because of your relative with hepatitis $B$ ?

\begin{tabular}{|l|l|l|}
\hline I'm anxious to share the same house & 8 & 7.5 \\
\hline $\begin{array}{l}\text { I am very afraid that the disease can be } \\
\text { transmitted to my children/grandchildren }\end{array}$ & 18 & 17 \\
\hline $\begin{array}{l}\text { I immediately had the test to see if I had the } \\
\text { germ }\end{array}$ & 55 & 51.9 \\
\hline I hesitate to have sexual intercourse & 11 & 10.4 \\
\hline I have health concerns about her/his life & 52 & 49.1 \\
\hline
\end{tabular}

\section{Discussion}

HBV infection is a global public health problem. In our country, vaccination and education studies in the prevention of infection are important since HBV infection is the endemic and horizontal transmission is prominent (5). This study aimed to measure the knowledge level of respondents concerning HBV infection and to determine their risk perceptions and attitudes. The patients in the study were followed by our clinic for more than a year. When the answers given to the questions measuring the level of knowledge about HBV were examined, $76.4 \%$ of the participants knew that hepatitis B was an infectious disease affecting the liver and $84.0 \%$ knew that inactive carriage could be seen. In a similar study conducted by Şenol (6) with the relatives of people with chronic hepatitis B in Istanbul, 90.4\% of the participants stated that HBV was an infectious disease, $94.2 \%$ of them stated that inactive carriage could be seen, and $80.8 \%$ of them stated that the carriers could transmit the disease to others (6). In another study conducted by Poyrazoğlu et al. (7) in Kayseri, $41.1 \%$ of relatives stated that hepatitis was a liver disease and an infectious disease, while $61.6 \%$ of them stated that the carriers could transmit the disease to others.

It is known that $15-20 \%$ of chronic hepatitis B cases may progress to icterus and $\operatorname{HCC}(8,9)$. In our study, $90.6 \%$ of the participants knew that the complications could lead to icterus, $45.3 \%$ to HCC, $41.5 \%$ to liver transplantation, and $39.6 \%$ to death. In the study of Senol (6), they found that $82.7 \%$ of the relatives knew that hepatitis B could cause icterus and HCC. In the study of Poyrazoğlu et al. (7), 93.8\% of the relatives of patients (patients with hepatitis B and C) stated that hepatitis could cause icterus and $39.3 \%$ of them stated that the disease could cause cancer. In a study conducted by Cheung et al. (10) with Chinese and Southeast Asians living in Canada, $68 \%$ of the participants were aware of HBV while more than $60 \%$ did not know the relationship between HBV and icterus or cancer. Our study and other studies conducted with relatives of patients showed that the level of knowledge about complications was higher in relatives than in the general population. The reason for this can be that relatives of patients have more information about hepatitis $B$ due to various concerns including their own health.

While $90.6 \%$ of the patients' relatives had undergone screening tests, only $49.1 \%$ of them received the vaccination, even though $89.6 \%$ of the participants had knowledge about the protective effects of vaccination. Similar to our study, in the study of Şenol (6), it was found that $32.7 \%$ of the people who should be vaccinated against HBV had not applied for vaccinations. It is rather interesting to see that, even though the importance of vaccination is so well understood, a significant proportion of individuals choose not to get vaccinated-despite being at high risk for transmission. In the study conducted by Bulut et al. (11), the percentage of individuals completing the HBV vaccination schedule was $63.3 \%$, and $12.1 \%$ of individuals did not even begin vaccination. In the same study, it was found that compliance with the vaccination schedule increased statistically with age (11). When the reasons for people not getting vaccinated were examined, the most common reasons were indifference, negligence, and lack of information (12). The vaccination rates of the risky population in our country are estimated to be around 5\%-an alarming figure by any standard. 
Therefore, it is important to organize training and educational approaches that encourage vaccination in both health professionals and at-risk groups (4).

In Turkey, in studies investigating the level of HBV-related information, it has emerged that there is an insufficient level of knowledge. Gökmenoğlu et al.'s study of dentistry students, an important risk group, showed that the level of knowledge was insufficient (1). However, in the same study, it was shown that the level of knowledge is better in the advancing classes with awareness and education studies. Again, in a study conducted by Özen in our country, it was reported that the level of knowledge is not sufficient even in hepatitis carriers (2). In reports from various underdeveloped countries, it has been observed that the level of knowledge and awareness of HBV in dental healthcare professionals (3), pregnant women (4), and healthcare professionals (5) are not sufficient. However, it is seen that all these deficiencies can be increased with various training programs and awareness programs. In our study, even in a group that is expected to have a high level of awareness about the disease, the insufficient level of knowledge shows that it is important to keep people informed about the issue.

\section{Study Limitations}

The limitations of our study are the relatively small number of patients, the fact that the questions were answered based on selfreporting, and the validity and reliability analysis of the questions asked were not performed. The other important limitation is that the data in the current study is relatively old and the statements and comments could be changed over time.

\section{Conclusion}

According to the findings of our study, the relatives of patients with HBV seem to have incomplete information about hepatitis $B$, while vaccination rates were found to be low. It is suggested that health professionals should give more importance to the education of patients and their relatives, especially during patient follow-up. In the fight against HBV infection, informing the whole society, especially patients with HBV and their relatives, about transmission routes and prevention of HBV transmission are vital. Our study is important because it is the first relatively large-scale study conducted with patient relatives in our country. However, multicenter studies with higher patient counts are needed to identify deficiencies in the society about hepatitis $B$, in order to address the lack of knowledge in the community and to provide education that will lead to behavioral changes.

\section{Ethics}

Ethics committee approval: This study was approved by the Institutional Ethics Review Committee of Ankara Yıldıım Beyazıt University Faculty of Medicine.
Informed Consent: Informed consent was obtained from them before they took the questionnaire.

Peer-review: Externally peer-reviewed.

\section{Authorship Contributions}

Surgical and Medical Practices: A.K.K., I.H., M.A.T., Concept: A.K.K., R.G., M.A.T., Design: A.K.K., R.G., M.A.T., Data Collection or Processing: A.K.K., G.R.Y., R.G., Analysis or Interpretation: A.K.K., I.H., M.A.T., Literature Search: A.K.K., I.H., M.A.T., Writing: A.K.K., R.G., FE., I.H., G.R.Y., M.A.T., Final approval: A.K.K., R.G., F.E., I.H., G.R.Y., M.A.T.

Conflict of Interest: The authors declare no conflict of interest.

Financial Disclosure: The authors declare that this study has not received any financial support.

\section{References}

1. Tang LS, Covert E, Wilson E, Kottilil S. Chronic hepatitis B infection: a review. JAMA. 2018;319:1802-1813.

2. Türk Karaciğer Araştırmaları Derneği, Viral Hepatitle Savaşım Derneği. Türkiye Viral Hepatitler Tanı ve Tedavi Kılavuzu; 2007.

3. Tozun N, Ozdogan O, Cakaloglu Y, Idilman R, Karasu Z, Akarca U, Kaymakoglu S, Ergonul O. Seroprevalence of hepatitis B and C virus infections and risk factors in Turkey: a fieldwork TURHEP study. Clin Microbiol Infect. 2015;21:1020-1026.

4. Güner R, Kalem AK, Hasanoğlu I, Keske S, Güven T, Yılmaz G. Hepatit B Virüsü ile Enfekte Hastaların Hastalık Hakkında Bilgi Düzeylerinin Değerlendirilmesi. Viral Hepatit Derg. 2012;18:29-33.

5. Tosun S. Hepatit B Așilamasi Ve Ülkemizde Hepatit Așilama Sonuçlari; 2014.

6. Şenol G. Kronik Hepatit B Hastası Olan Kişilerin Yakınlarının Aşılanma Oranları Ve Hastalık Konusunda Bilgi Ve Tutumlarının Değerlendirilmesi T.C. Istanbul Üniversitesi Cerrahpaşa Tıp Fakültesi Aile Hekimliği Anabilim Dalı, Uzmanlık Tezi.

7. Poyrazoğlu S, Baykan Z, Naçar M, Çetinkaya FHB. C'li hasta yakınlarının hepatitler hakkındaki bilgi düzeyleri ve risk algıları. Viral Hepatit Derg. 2009;14:108-115.

8. Tabak F. Viral hepatitler. IÜ Cerrahpaşa Tıp Fakültesi Sürekli Tıp Eğitimi Etkinlikleri Türkiye'de Sık Karşılaşılan Hastalıklar Sempozyum Dizisi. 2007;55:195-214.

9. Shepard CW, Simard EP, Finelli L, Fiore AE, Bell BP. Hepatitis B virus infection: epidemiology and vaccination. Epidemiol Rev. 2006;28:112-125.

10. Cheung J, Lee TK, Teh CZ, Wang CY, Kwan W, Yoshida EM Cross-sectional study of hepatitis B awareness among Chinese and Southeast Asian Canadians in the Vancouver-Richmond community. Canadian Journal of Gastroenterology and Hepatology. 2005;19:245-249.

11. Bulut C YaM, Tülek N. Hepatit B Aşısına Uyum ve Uyumu Etkileyen Faktörler. Viral Hepatit Dergisi. 2003;8:25-31.

12. Tosun S KA, Yaren Ü, Öztürk $\mathrm{O}$, Alpgiray a, Köroğlu G. Aile Hekimlerinin Viral Hepatitler Hakkındaki Bilgi Düzeylerinin Değerlendirilmesi; 2012. 